\title{
ANALISIS FUNDAMENTAL, ACUAN INVESTASI SAHAM JANGKA PANJANG
}

Rachma Agustina, M.Pd. M.Ak., Universitas Hasyim Asy'ari Tebuireng Jombang, rachma.agustina1@gmail.com

\begin{abstract}
:
Stock investors certainly expect maximum profits in their investments in the stock market, both long-term investments and short-term investments. There are two analyzes that can be used to make predictions from the prospect of stock profits. Fundamental Analysis for long term investment and Technical Analysis for short term investment. Understanding the importance of these two analyzes is a provision for investors to be able to analyze, make predictions and then determine which stocks can be profitable now and in the future. The selection of these stocks can add to the investor's portfolio in order to be more productive and get maximum profit. The Community Service Program is focused on the use of fundamental analysis for novice investors, by utilizing the existing financial reports on the IDX web.
\end{abstract}

Keywords: Fundamental Analysis, Financial Statements, Long Term Investment

\begin{abstract}
Abstrak:
Investor saham pasti mengharapkan keuntungan maksimal dalam investasinya di pasar saham, baik investasi jangka panjang maupun investasi jangka pendek. Untuk membuat prediksi dari prospek keuntungan saham terdapat dua analisis yang bisa dipergunakan. Analisis Fundamental untuk investasi jangka panjang dan Analisis Teknikal untuk investasi jangka pendek. Pemahaman pentingnya kedua analisis ini merupakan bekal bagi para investor untuk bisa menganalisis, membuat prediksi kemudian menentukan sahamsaham mana yang sekiranya bisa menguntungkan di saat ini maupun masa yang akan datang. Pemilihan saham-saham tersebut bisa menambah portofolio investor agar lebih menghasilkan dan mendapatkan keuntungan maksimal. Program Pengabdian Kepada Masyarakat difokuskan pada penggunaan analisis fundamental bagi investor pemula, dengan memanfaatkan laporan keuangan yang sudah ada dalam web IDX.
\end{abstract}

Kata Kunci: Analisis Fundamental, Laporan Keuangan, Investasi Jangka Panjang

\section{PENDAHULUAN}

Kondisi pandemic yang terjadi sejak pertengahan 2019 membuat semua sector harus menyesuaikan diri dan bertahan terhadap krisis yang belum diketahui kapan akan berakhir. Bidang ekonomi terutama penanaman modal investasi termasuk dalam salah satu sector yang beberapa kali harus mengalami penghentian sementara perdagangan (trading halt), tercatat sejak Maret 2020 sampai September 2020 telah terjadi trading halt sebanyak 7 kali. Penghentian sementara perdagangan sesuai dengan SK Direksi PT BEI No: Kep-00024/BEI/03-2020 tertanggal 10 Maret 2020 mengenai Perubahan Panduan

Copyright ( 2021, Dinamis: Jurnal Pengabdian Kepada Masyarakat https://ejournal.feunhasy.ac.id/dinamis 
Penanganan Kelangsungan Perdagangan di Bursa Efek Indonesia dalam Kondisi Darurat (Wareza, 2020). Gambaran trading halt dapat dilihat pada tabel dibawah ini:

Tabel 1. Trading Halt Maret - September 2020

PENCATATAN PELAKSANAAN HALT TRADING

\begin{tabular}{|c|c|c|c|c|}
\hline No. & Tanezal & $\begin{array}{l}\text { Pelaksanaan Halt } \\
\text { Trading (IATS) }\end{array}$ & $\frac{\text { Pembukaan Halt }}{\text { Trading (JATS) }}$ & Posisi IHSG \\
\hline 1. & 12 Maret 2020 & 15:33:58 & $16: 05: 58$ & $\begin{array}{l}\text { - IHSG: } 4.895,74 \\
\text { - Penurunan }=5 \%\end{array}$ \\
\hline 2. & 13 Maret 2020 & 09:15:33 & 09:45:33 & $\begin{array}{l}\text { - IHSG: } 4.650,58 \\
\text { - Penurunan }=5 \%\end{array}$ \\
\hline 3. & 17 Maret 2020 & $15: 02: 44$ & 15:32:44 & $\begin{array}{l}\text { - IHSG: } 4.456,09 \\
\text { - Penurunan }=5 \%\end{array}$ \\
\hline 4. & 19 Maret 2020 & 09:37:18 & 10:07:18 & $\begin{array}{l}\text { - IHSG: } 4.113,64 \\
\text { - Penurunan }=5 \%\end{array}$ \\
\hline 5. & 23 Maret 2020 & 14:52:09 & 15:22:09 & $\begin{array}{l}\text { - IHSG: } 3.985,07 \\
\text { - Penurunan }=5 \%\end{array}$ \\
\hline 6. & 30 Maret 2020 & 10:20:48 & 10:50:48 & $\begin{array}{ll}\text { - IHSG: } 4.318,29 \\
\text { - } & \text { Penurunan }=5 \%\end{array}$ \\
\hline 7. & $\begin{array}{l}10 \text { September } \\
2020\end{array}$ & 10:36:18 & 11:06:18 & $\begin{array}{l}\text { - IHSG: } 4.891,87 \\
\text { - Penurunan }=5 \%\end{array}$ \\
\hline
\end{tabular}

Sumber: CNBC, 2020

Penghentian sementara tersebut tidak serta merta membuat bursa saham menjadi sepi meskipun pasang surut juga tidak bisa dihindari, kondisi berangsur-angsur mengalami peningkatan ketika akhir-akhir tahun 2020. Tercermin dari pergerakan grafik IHSG yang bisa kembali ke angka 6000. Turun pada 0,95\% indeks kembali 5979 di medio 30 Desember 2020. Pihak OJK sendiri sudah membuat kebijakan pencegahan dan luar biasa guna tetap menjagai stabil dan kepercayaan di pasar saham. Pertama, dengan paket kebijakan yang digunakan untuk mengatur volatility pasar modal yang dikeluarkan sejak akhir Februari 2020. Diantaranya dengan melarang terjadinya short sellin, memberlakukan trading halt pada $5 \%$ penurunan dan auto rejection asymmetric, diperpendeknya jam kerja bursa, dan pembelian kembali saham oleh emiten tanpa melewati RUPS ketika kondisi pasar mengalami fluktuasi. Kedua, adanya pelonggaran bagi industry di pasar modal supaya bisa survive di masa pandemic seperti saat ini, diantaranya dengan adanya kebijakan dilaksanakan RUPS melaui elektronik, pelonggaran disampaikan dan perpanjangan masa berlaku laporan keuangan, juga memberikan insentif dan pemotongan biaya dari Self Regulatory Organization. Ketiga, memudahkan cara melaporkan dan memberikan izin pada pelaku pasar modal dnegan memaksimalkan manfaat teknologi semisal menggunakan elektronik tanda tangan ketika proses pengurusan izin dan pelaporan (BeritaSatu.com, 2021).

Badan Koordinasi Penanaman Modal (BKPM) telah mencatat terjadinya investasi langsung pada perempat pertama tahun 2021 dengan nilai Rp 219,7 triliun. Dari angka tersebut bisa diketahui tumbuh $4,3 \%$ dibandingkan dnegan kenyataan di periode sama pada tahun sebelumnya. Selanjutnya jika dibanding hasil perempat IV-2020, direct investmen pada perempat pertama 2021 bisa mencapai 2,4\%. Apabila dirinci sesuai muasalnya, investasi langsung tersebut bersumber dari penanaman modal dalam negeri dengan nilai Rp 108 triliun juga penanaman modal asing dengan besasarn Rp 111,7 triliun. Nilai-nilai tersebut di perempat pertama 2021 menunjukkan naiknya perbandingan 
hasil catatan perempat ketiga 2020. Dengan rincian pertumbuhan, capaian 4,2\% dan $14 \%$. Ada garis bawah dari BKPM pada sumbangan dari PMA seimbang pada 50,8\% dari jumlah total investasi nyata pada trimester pertama tahun ini. Kepala BKPM pada awal pekan ini menyampaikan bahwa "hal tersebut memberikan petunjuk bahwa kepercayaan dunia tumbuh atas iklim penanaman modal juga potensi penanaman modal di Indonesia," (Hadiwinata, 2021) .

Sejalan dengan usaha-usaha pemerintah untuk meningkatkan kembali iklim investasi di Indonesia, para investor juga harus jeli dalam melihat peluang pasar. Bagi para investor pemula yang masih harus menambah pengalaman dalam trading saham, maka perlu memahami lebih dahulu analisis-analisis yang digunakan dalam menilai kelayakan saham untuk dimasukkan dalam portofolionya. Kedua analisis tersebut sejatinya tidak bisa dipisahkan karena perannya saling mendukung dalam penilaian kelayakan suatu saham untuk dibeli. Seringkali ada pembedaan penggunaan kedua analisis tersebut. Analisis fundamental digunakan bagi analisis saham-saham yang ditujukan untuk investasi jangka panjang. Sedangkan analisis teknikal dipakai untuk menganalisis saham-saham yang focus ke trading, atau jual beli saham dalam jangka waktu pendek.

Sebagaimana Jogiyanto (2008) yang mengungkapkan bahwa terdapat dua jenis cara analisis guna mengetahui nilai saham, yaitu terdiri dari informasi yang bersifat teknikal dan fundamental. Informasi fundamental didapatkan dari dalam entitas diantaranya deviden dan pertumbuhan hasil penjualan produk dari emiten, adapun informasi yang bersifat teknikan didapatkan dari luar emiten semisal tentang keuangan, perpolitikan, situasi ekonomi dsb.

Apabila informasi yang bersifat fundamental merupakan informasi yang ada hubungannya dengan kondisi emiten umumnya terdapat di dalam financial statement dan menjadi salah satu cara mengukur kinerja emiten. Analisis fundamental seringkali dipakai guna membuat prediksi tentang harga-harga saham. Analisis tersebut kemudian dibagi lagi menjadi variabel fundamental internal berisi info-info tentang kinerja emiten dan variabel eksternal untuk kondisi secara umum dan global. Jadi analisis teknikal adalah studi untuk market behavior yang kemudian dilihat dan diprediksi kecenderungan dari harga yang akan muncul pada masa depan dengan lewat grafik (Murphy, 1999). Analisis ini menjadi dasar keputusan penanaman modal dari data harga dan isi yang ada sebelumnya untuk sumber informasi (Reilly \& Brown, 2012). Informasi tentang market price dan volume transaksi dari perusahaan sekuritas yang sudah ada kemudian diolah dengan statistik guna membantu untuk memperhatikan peluang-peluang dari pergerakan harga saham di masa depan (Ong, 2012).

Pelatihan ini difokuskan pada penggunaan analisis fundamental didasari alasan pentingnya para investor di GI BEI Fakultas Ekonomi Universitas Hasyim Asy'ari Tebuireng Jombang untuk memahami Analisis Fundamental. Sehingga investasi yang dijalankan bukan hanya terlaksana pada saat ketika menjadi mahasiswa atau selama menempuh pendidikan, namun bisa bertahan seterusnya karena dengan analisis 
fundamental ini investor bisa memilih saham-saham yang sekiranya bisa bertahan lama dan mendapatkan keuntungan dari pembagian deviden secara kontinyu sesuai peraturan yang ditetapkan emiten.

\section{METODE KEGIATAN}

PKM dilaksanakan melalui online dengan media zoom cloud meeting. Pemilihan metode tersebut didasarkan pada situasi yang tidak memungkinkan untuk pertemuan tatap muka langsung dengan adanya pandemic yang terjadi saat ini. Dilaksanakan pada tanggal 18 Maret 2021 bersama para investor Galeri Investasi Bursa Efek Indonesi di Fakultas Ekonomi Universitas Hasyim Asy'ari Tebuireng Jombang. Pelaksanaan program ini dilakukan dalam 3 tahap, pra kegiatan dengan menggali pengetahuan dasar para investor tentang analisis fundamental, tahap kedua merupakan kegiatan utama dengan pemberian materi dan informasi-informasi mengenai analisis fundamental, tahap terakhir atau tahap ketiga dengan mengevaluasi pemahaman investor terhadap materi yang sudah diberikan sebelumnya.

\section{HASIL DAN PEMBAHASAN}

Husnan (2008) mendefinisikan saham sebagai lembaran kertas yang isinya memberi petunjuk tentang hak-hak dari pemilik modal yaitu yang mempunyai kertas tersebut guna mendapatkan bagian dari kekayaan entitas penerbit sekuritas, juga bermacam situasi yang memberikan kemungkinan pemilik modal itu melaksanakan hak. Terdapat 4 jenis harga saham yaitu:

a. Harga nominal, adalah harga yang terdapat pada sertifikat saham sesuai ketetapan emiten guna menilai tiap lembaran saham yang sudah keluar.

b. Harga IPO, yaitu harga ditetapkan oleh penjamin emisi (underwrite) dan emiten saat IPO

c. Harga pasar, yaitu harga jual dari investor yang satu dengan investor yang lain

d. Harga pembukaan, yaitu harga yang diminta oleh penjual atau pembeli pada saat jam bursa dibuka

e. Harga penutupan, yaitu harga yang diminta oleh penjual atau pembeli pada saat akhir hari bursa.

Kelebihan berinvestasi saham dibandingkan produk investasi lain adalah sebagai berikut (Fitrya. 2018)

a. Modal yang dibutuhkan relatif kecil, karena tidak semua saham harganya mahal

b. Relatif mudah dilakukan, terutama jika telah mendownloiad aplikasi yang disediakan oleh perusahaan sekuritas tertentu

c. Bisa dilakukan oleh siapa saja, kapan saja, dan dimana saja, selama terhubung dengan gadget yang terkoneksi internet 
d. Bersifat transparan dan likuid

e. Pergerakan harga mengikuti inflasi

f. Aman, karena dijamin dan pengawasan berkala yang dilakukan oleh otoritas bursa kepada perusahaan sekuritas maupun pergerakan harga saham

g. Menguntungkan dalam jangka pendek maupun jangka panjang

Sedangkan resiko berkenaan dengan investasi saham adalah sebagai berikut (Fitriya, 2018):

a. High risk, high return. Terutama untuk saham yang digoreng oleh bandar

b. Fluktuasi harga, karena adakalanya harga naik dan turun

c. Mesti dipantau secara berkala, karena perdagangan saham dilakukan secara harian, sehingga potensi kenaikan atau penurunan harga terjadi setiap hari

d. Perlu bantuan orang lain (trader saham, analis saham) untuk menetapkan saham yang tepat dibeli, jika tidak memiliki akses ke pergerakan harian saham

e. Suspensi saham oleh otoritas bursa, sehingga saham tidak dapat diperjualbelikan untuk jangka waktu tertentu

f. Delisting saham oleh otoritas bursa, sehingga saham tidak lagi bisa diperdagangkan di bursa

Investor yang tergabung di GI BEI FE UNHASY Tebuireng Jombang terdiri dari berbagai latar belakang yang tidak hanya dari orang-orang dengan latar belakang pendidikan ekonomi, atau yang memahami tentang analisis-analisis dalam memilih saham. Seperti informasi yang terjaring oleh penulis dalam beberapa kali dialog dengan investor, biasanya investor membeli saham berdasarkan insting atau mengikuti saran dari orang - orang yang dianggap paham mengenai trading saham. Sehingga para investor tersebut hanya bergantung dan menunggu informasi dari orang lain untuk bisa memilah dan menentukan saham-saham mana yang bisa dibelinya.

Analisis fundamental adalah sebuah teknik analisis yang menitikberatkan pada analisis kinerja perusahaan serta bagaimana proyeksi kondisi ekonomi di masa datang mempengaruhi bisnis saham emiten, sehingga investor saham dapat menetapkan apakah keputusan bid (beli) atau sell (jual) saham dapat dilakukan saat itu dengan harga tertentu (Sutrisno, 2012). Pada analisis fundamental, informasi tentang laporan keuangan merupakan cara utama yang dipakai para analis di sekuritas untuk mengambil keputusan penanaman modal. Informasi ini diantaranya tentang informasi akuntansi yang terdapa di laporan keuangan, isinya tentang informasi yang sanngat berguna untuk penganbilan keputusan bergagai pihak (Sugir, 2004). Adapun bentuk dari informasi dalam laporan keuangan tersebut adalah rasio yang kemudian dipakai untuk mengukur kinerja entitas dibidang keuangan, kemudian di umumkan guna dipakai oleh investor. Berbagai definisi tersebut membuat penulis sebagai pemateri pada kegiatan ini mengambil kesimpulan bahwa analisis fundamental adalah analisis yang dilakukan dengan cara mempelajari banyak hal yang berkaitan dengan kekuatan mendasar dari suatu perusahaan. Analisis ini tidak hanya berfokus pada kinerja pergerakan saham, tetapi juga kinerja bisnis secara keseluruhan. 


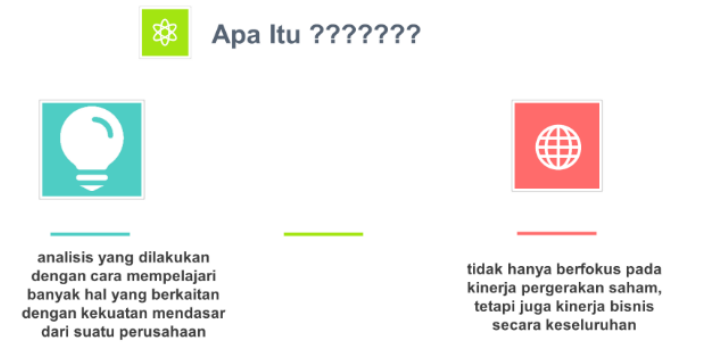

Gambar 1. Ilustrasi Definisi Analisis Fundamental

Perbedaan dari dua analisis saham: fundamental dan teknikal bisa dilihat dari berbagai sisi, yaitu:

Tabel 2. Perbedaan Analisis Fundamental dan Analisis Teknikal

\begin{tabular}{|l|l|l|}
\hline \multicolumn{1}{|c|}{ Hal } & \multicolumn{1}{|c|}{ Analisis fundamental } & \multicolumn{1}{c|}{ Analisis teknikal } \\
\hline Alat analisis & $\begin{array}{l}\text { Menggunakan laporan } \\
\text { keuangan }\end{array}$ & $\begin{array}{l}\text { Menggunakan grafik } \\
\text { harga saham }\end{array}$ \\
\hline Jangka Waktu Investasi & Jangka panjang & Jangka pendek \\
\hline Keuntungan yang diperoleh & Deviden & Capital gain \\
\hline Syarat Khusus & Pasar efisien & Pasar tidak efisien \\
\hline
\end{tabular}

Sumber: Data diolah penulis, 2021

Perbedaan tersebut:

1. Analisis fundamental menggunakan alat analisis berupa laporan keuangan yang tertera di BEI atas nama emiten, disusun oleh entitas emiten dan telah di audit oleh auditor eksternal. Laporan keuangan yang digunakan adalah neraca, laporan perubahan modal, laporan laba rugi, arus kas dan catatan atas laporan keuangan. Sehingga benar-benar melihat dari track record dan naik turunnya angka-angka dari rasio yang muncul dari perhitungan berdasarkan laporan keuangan tersebut. Sedangkan analisis teknikal melihat dari grafik-grafik naik turunnya harga saham dengan berbagai cara, diantaranya candle stick dll.

2. Dari sisi jangka waktu investasi, analisis fundamental diperuntukkan bagi investasi dalam jangka panjang dalam arti tidak terlalu cepat untuk jual dan belinya. Sedangkan teknikal diperuntukkan bagi investor yang berminat untuk trading sehingga berlaku untuk jangka pendek saja.

3. Keuntungan yang diharapkan pada penggunaan analisis fundamental adalah diperolehnya pembagian deviden yang tinggi dan teratur waktunya. Teknikal diharapkan mendapatkan keuntungan dari capital gain atau keuntungan dari transaksi cepat jual dan beli saham.

4. Penggunaan analisis fundamental bisa berjalan dengan baik apabila pasar efisien, dalam arti pasar dapat memberikan informasi kepada investornya secara cepat dan tidak dikenakan biaya, ada kompetisi yang sempurna, tidak dibatasi, dan semua individu memaksimumkan ekspektasi utilitasnya secara rasional. Untuk analisis 
teknikal bisa digunakan meskipun pasar tidak efisien, ini menunjukkan bahwa tidak semua investor bisa cermat dan telaten dalam mengamati pergerakan grafik saham.

Analisis Fundamental bisa dilakukan dengan dua pendekatan, yaitu:

1. Pendekatan top down

2. Pendekatan bottom up

Kedua pendekatan tersebut menggunakan informasi-informasi yang berkaitan mengenai:

1. Analisa Ekonomi Makro, meliputi informasi mengenai PDB, Inflasi, Tingkat Bunga, Fluktuasi Nilai Tukar dan hal-hal lain yang sedang menjadi trend ekonomi secara global saat ini.

2. Analisa Industri, meliputi informasi-informasi mengenai industry emiten yang akan dibeli sahamnya oleh investor. Informasi tersebut meliputi penjualan, laba, deviden, regulasi dan inovasi, semuan informasi tersebut harus dalam lingkup industry yang sama dengan emiten tujuan investor.

3. Analisa Perusahaan (kinerja keuangan), meliputi informasi-informasi spesifik emiten yang dituju investor yaitu dari laporan keuangan yang sudah tersedia di web IDX dan bisa diakses masyarakat umum, kemudian dilakukan penghitungan sederhana untuk mengetahui rasionya. Rasio-rasio inilah yang kemudian menjadi pertimbangan utama dalam memilih saham. Rasio profitabilitas dari Net Profit Margin, Rasio Price dari Price Earning Rasio dan Rasio Leverage dari Debt to Equity Ratio.

Gambaran dari pendekatan top down adalah seperti gambar dibawah menggunakan informasi analisa ekonomi makro terlebih dahulu baru kemudian menurun pada penentuan industry yang kemudian dianalisa dan terakhir memilih emiten yang akan di analilis kinerja keuangannya. Berkebalikan dengan pendekatan bottom up yang posisi piramidanya terbalik dari top down, mengindikasikan yang dianalisa adalah kinerja keuangan dari emiten, dilanjutkan dnegan analisa industry dan terakhir analisa ekonomi makro.

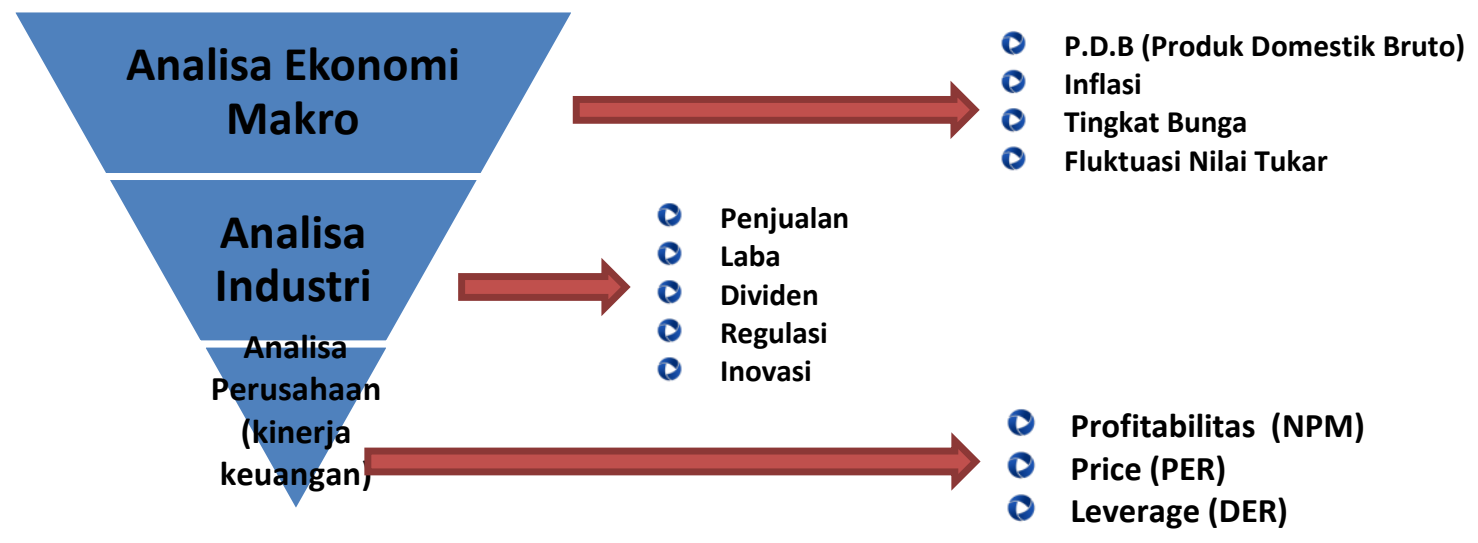

Gambar 2. Ilustrasi Pendekatan Top Down pada Analisis Fundamental Sumber: Data diolah penulis, 2021

Informasi kinerja keuangan perlu diperbadingkan dalam beberapa tahun sehingga bisa dilihat naik turunnya rasio-rasio tersebut. Rasio tersebut adalah: 
1. EPS (Earning Per Share) merupakan tingkat profit netto untuk per lembar saham yang memang bisa dicapai entitas ketika melaksanakan proses produksi. Rasio ini didapatkan dari laba yang memang disediakan untuk investor saham biasa dibagi dengan jumlah rerata saham biasa yang sudah beredar. Informasi tentang EPS ini sudah tercantum dalam laporan keuangan (laporan laba rugi dan penghasilan komprehensif lain) sehingga investor tidak perlu menghitung EPS.

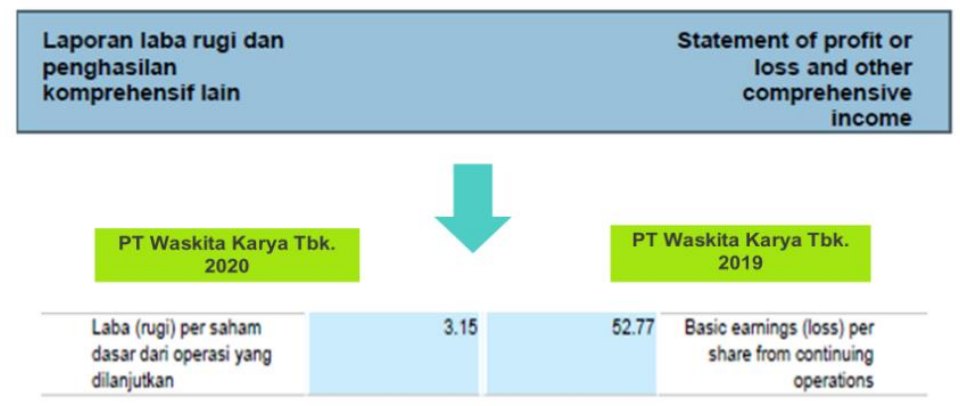

Gambar 3. Ilustrasi Pencarian EPS dalam Laporan Keuangan Emiten Sumber: Data diolah penulis, 2021

Untuk yang familiar dengan gadget maka bisa menggunakan aplikasi RTI Business dengan langkah-langkah seperti tercantum dalam ilustrasi sbb:

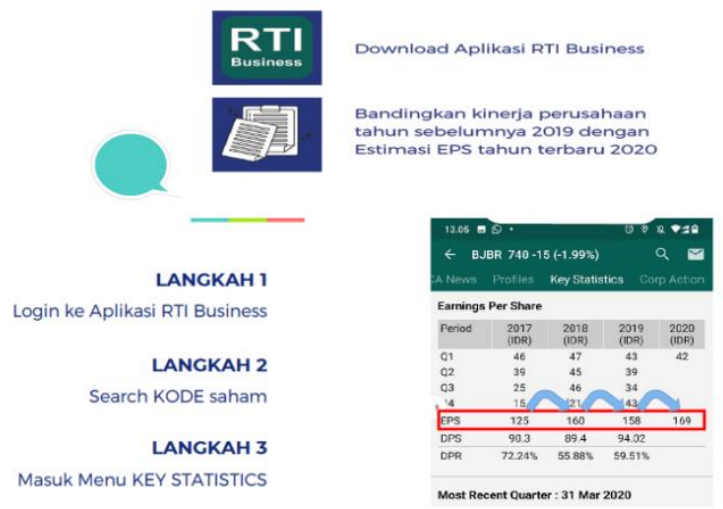

Gambar 4. Ilustrasi Pencarian EPS dalam Aplikasi RTI Business Sumber: Data diolah penulis, 2021

2. NPM (Net Profit Margin) adalah menunjukan besarnya presentase laba bersih yang diperoleh dari setiap penjualan. Semakin besar rasio ini, maka bisa dianggap semakin baik kemampuan perusahaan untuk mendapatkan laba yang tinggi. Rasio NPM yang bagus adalah rasio NPM yang mengalami tren kenaikan setiap tahunnya, dihitung menggunakan rumus: (Laba Bersih : Penjualan Bersih) x 100\%

3. PER (Price Earning Ratio) adalah merupakan rasio yang menggambarkan harga saham sebuah perusahaan dibandingkan dengan keuntungan atau laba yang dihasilkan perusahaan tersebut (EPS). Rasio ini bisa dihitung dengan rumus = harga saham : pendapatan per saham (EPS). Jika PER kurang dari rerata emiten lain pada industry yang sama, maka harga dari entitas dianggap lebih murah. PER rendah memang diminati investor. Sedangkan PER tinggi bisa dijadikan acuan bawha nilai 
saham tinggi juga ada pertumbuhan, PER dengan nilai rendah sering dianggap sebagai saham bernilai atau value stocks. Dengan kata lain, saham yang dijual harganya lebih rendah dari harga pasar. Para investor bisa membeli saham itu sebelum pasar melakukan peninjauan ulang saham tersebut. Value stocks juga berpotensi mendapatkan nilai fundamental yang tinggi ke depannya.

4. DER (Debt to Equity Ratio) adalah rasio untuk melihat berapa besar utang dibandingkan total ekuitas (modal) yang dimiliki perusahaan. Utang yang besar bisa menimbulkan rasio pada entitas. Rumusnya $=$ Total Hutang $:$ Total Modal.

Untuk melakukan penilaian kesehatan hutang pada entitas, yang dapat menjadi acuan ketika membuat analisa adalah :

DER lebih dari 1 memiliki arti hutang entitas lebih besar dari ekuitas.

DER kurang dari 1 memiliki arti hutang entitas lebih kecil daripada ekuitas

Perusahaan yang baik adalah perusahaan yang memiliki DER $<1$, hal ini menunjukkan utang masih dapat ditoleransi.

Panduan untuk menggunakan rasio-rasio ini adalah:

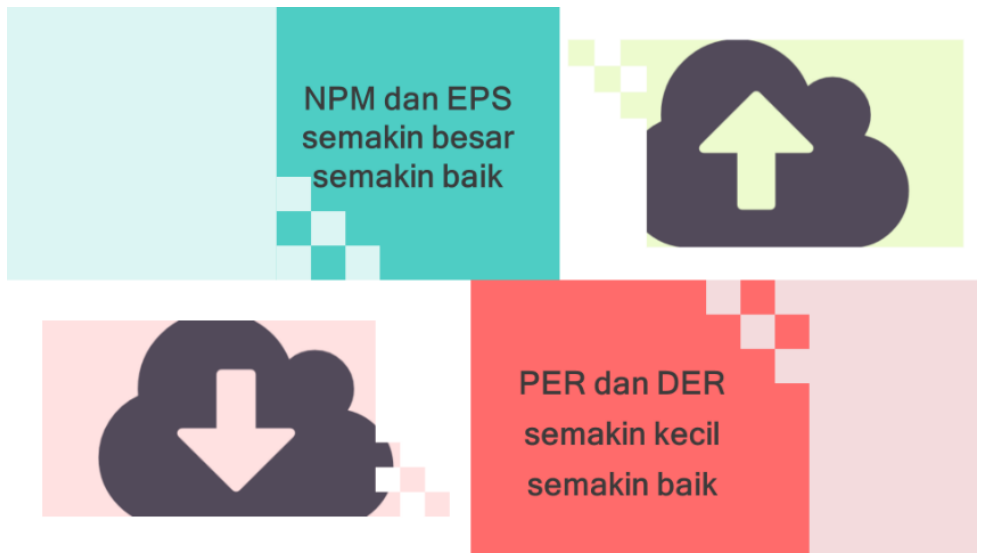

Gambar 5. Ilustrasi Panduan Analisis Perbandingan Rasio

Sumber: Data diolah penulis, 2021

Untuk program pengabdian kepada masyarakat dikesempatan ini menggunakan laporan keuangan kuartal 1 dari PT Waskita Karya dan PT WIKA, yang berada pada satu industry infrastruktur. Kemudian diperbandingkan rasio laporan keuangan dari 4 tahun sejak 2017 sampai 2020. Dari hasil perhitungan rasio-rasio tersebut didapatkan hasil :

Tabel 2. Penghitungan Rasio Keuangan

Berdasar Laporan Keuangan Q1 WSKT

\begin{tabular}{|l|r|r|r|r|}
\hline \multicolumn{1}{|c|}{ (dalam juta) } & \multicolumn{1}{c|}{$\mathbf{2 0 2 0}$} & \multicolumn{1}{c|}{$\mathbf{2 0 1 9}$} & \multicolumn{1}{c|}{$\mathbf{2 0 1 8}$} & \multicolumn{1}{c|}{$\mathbf{2 0 1 7}$} \\
\hline Laba Bersih & 10,179 & 795,075 & $1,735,544$ & 425,671 \\
\hline Penjualan Bersih & $4,169,887$ & $8,682,208$ & $12,396,894$ & $7,354,796$ \\
\hline NPM & $0.24 \%$ & $9.16 \%$ & $14 \%$ & $5.79 \%$ \\
\hline EPS & 3.15 & 52.77 & 112.29 & 27.09 \\
\hline Market Price & 476 & 1985 & 2470 & 2370 \\
\hline PER & $151 \mathrm{x}$ & $37.62 \mathrm{x}$ & $21,99 \mathrm{x}$ & $87.49 \mathrm{x}$ \\
\hline Total Hutang & $89,095,812$ & $93,470,790$ & $86,682,150$ & $75,140,936$ \\
\hline
\end{tabular}


Rachma Agustina: Analisis Fundamental, Acuan Investasi Saham Jangka

Panjang

\begin{tabular}{|l|r|r|r|r|}
\hline Total Modal & $27,270,050$ & $29,118,469$ & $24,491,656$ & $22,754,824$ \\
\hline DER & 3.27 & 3.21 & 3.54 & 3.30 \\
\hline
\end{tabular}

Sumber: Data diolah penulis, 2021

Tabel 3. Penghitungan Rasio Keuangan

Berdasar Laporan Keuangan Q1 WSKT Q1 WIKA

\begin{tabular}{|l|r|r|r|r|}
\hline \multicolumn{1}{|c|}{ (dalam juta) } & \multicolumn{1}{c|}{$\mathbf{2 0 2 0}$} & \multicolumn{1}{c|}{$\mathbf{2 0 1 9}$} & \multicolumn{1}{c|}{$\mathbf{2 0 1 8}$} & \multicolumn{1}{c|}{$\mathbf{2 0 1 7}$} \\
\hline Laba Bersih & 152 & 341 & 215 & 265 \\
\hline Penjualan Bersih & 4,199 & 6,504 & 6,257 & 3,813 \\
\hline NPM & $3.62 \%$ & $5.24 \%$ & $3.44 \%$ & $6.95 \%$ \\
\hline EPS & 11.07 & 31.87 & 19.1 & 27.34 \\
\hline Market Price & 880 & 2160 & 1680 & 2410 \\
\hline PER & $79.5 \mathrm{x}$ & $67.84 \mathrm{x}$ & $87.96 \mathrm{x}$ & $88.15 \mathrm{x}$ \\
\hline Total Hutang & 44,324 & 43,410 & 35,439 & 31,051 \\
\hline Total Modal & 16,791 & 16,640 & 14,733 & 14,631 \\
\hline DER & 2.64 & 2.61 & 2.41 & 2.12 \\
\hline
\end{tabular}

Sumber: Data diolah penulis, 2021

Dari hasil perbandingan rasio kemudian investor dapat memilih saham dari emiten mana yang lebih layak untuk dijadikan investasi jangka panjang.

Selain pemahaman tentang Analisis fundamental, pada kesempatan PKM ini juga diberikan tambahan informasi mengenai IHSG, indek LQ45, indeks IDX80, dan indeks untuk saham syariah JII 30. Penjelasan masing-masing indeks tertera dalam ilustrasi sbb:

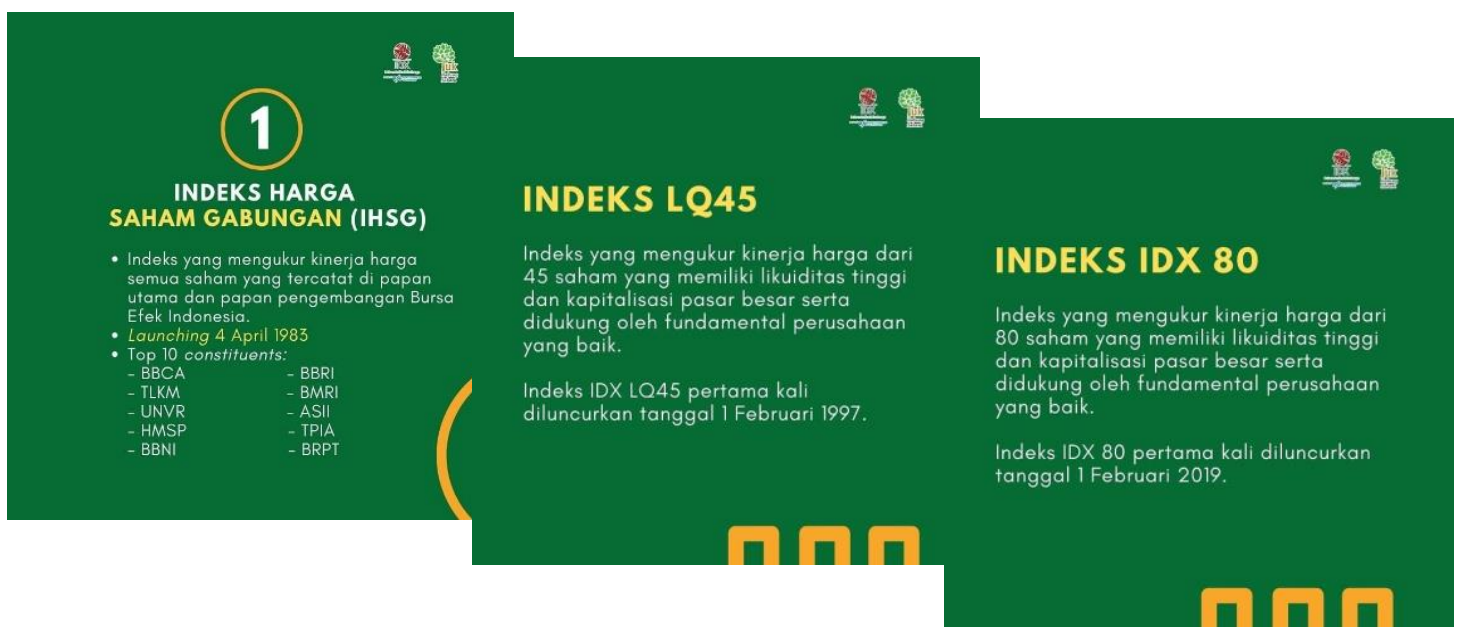

Gambar 6. Ilustrasi IHSG, LQ 45, IDX 80

Sumber: IG IDX, 2021

JII (Jakarta Islamic Index) 30 adalah 30 Emiten yang di seleksi dari kurang lebih 360 emiten dan dipilih yang paling Liquid, serta sesuai dengan Prinsip - Prinsip syariah. Seleksi dilakukan Bulan Mei dan Bulan November. Emiten yang lebih dari 5 tahun selalu 
ada di JII 30 hingga agustus 2019, adalah:

$\S$ INCO (Vale Indonesia) - 1996

$\S \operatorname{KLBF}($ Kalbe farma) - 2003

$\S$ PTBA ( Batu Bara Bukit Asam) - 2002

$\S$ UNVR ( Unilever Indonesia) - 1991

$\S$ TLKM ( Telkomunikasi Indonesia) - 1995

$\S$ UNTR ( United Tractors) - 1989

\section{KESIMPULAN}

Bagi para investor pemula yang masih harus menambah pengalaman dalam trading saham, maka perlu memahami lebih dahulu analisis-analisis yang digunakan dalam menilai kelayakan saham untuk dimasukkan dalam portofolionya. Kedua analisis tersebut sejatinya tidak bisa dipisahkan karena perannya saling mendukung dalam penilaian kelayakan suatu saham untuk dibeli. Seringkali ada pembedaan penggunaan kedua analisis tersebut. Analisis fundamental digunakan bagi analisis saham-saham yang ditujukan untuk investasi jangka panjang. Sedangkan analisis teknikal dipakai untuk menganalisis saham-saham yang focus ke trading, atau jual beli saham dalam jangka waktu pendek.

Analisis fundamental merupakan analisa yang dilakukan dengan mengetahui dan belajar banyak hal yang ada kaitannya dnengan kekuatan fundament entitas penerbit saham. Analisis ini tidak hanya berfokus pada kinerja pergerakan saham, tetapi juga kinerja bisnis secara keseluruhan. Analisis ini dapat dihitung dengan menggunakan perbandingan rasio dari tahun ke tahun yang bersumber dari laporan keuangan emiten, rasio tersebut adalah Earning Per Share, Net Profit Margin, Price to Earning Ratio dan Debt to Equity Ratio.

\section{DAFTAR PUSTAKA}

BeritaSatu.com. (2021, Maret 2). Setahun Covid-19, IHSG Rebound Lampaui Sebelum Era Pandemih. https://www.beritasatu.com/ekonomi/740253/setahun-covid19ihsg-rebound-lampaui-sebelum-era-pandemi, diakses 17 Juni 2021.

Fitriya. (2018, January 18). 8 Alasan Ini Akan Membuat Anda Memilih Investasi Saham. https://www.cermati.com/artikel/8-alasan-ini-akan-membuat-anda-memilihinvestasi-saham, diakses 15 Pebruari 2021

Hadiwinata, Thomas. (2021, April 28). Seperti Ini Pertumbuhan Investasi Langsung di Indonesia selama Kuartal I-2021. https://insight.kontan.co.id/news/seperti-inipertumbuhan-investasi-langsung-di-indonesia-selama-kuartal-i-2021, diakses 17 Juni 2021.

Husnan, Suad. 2008. Dasar-Dasar Manajemen Keuangan. Yogyakarta: UPP YKPN

Jogiyanto. 2008. Teori Portofolio dan Analisis Investasi. Edisi Kedua, BPFE UGM, Yogyakarta.

Copyright ( 2021 , Dinamis: Jurnal Pengabdian Kepada Masyarakat http://ejournal.feunhasy.ac.id/dinamis 
Murphy, J. J. (1999). Technical Analysis of The Financial Markets: A Comprehensive Guite to Trading Methods and Aplication. London: Penguin.

Ong, E. (2012). Technical Analysis for Mega Profit (Edisi *). Jakarta: PT. Gramedia Pustaka Utama.

Reilly, B., \& Brown, K. C. (2012). Invesment Analysis and Portofolio Management, Tenth International Edition (Tenth). Ohio: South-Western, Cengage Learning.

Sutrisno. 2012. Manajemen Keuangan: Teori, Konsep, Aplikasi. Yogyakarta: EKONISIA.

Wareza, Monica. (2020, September). Sudah 7 Kali Trading Halt Bursa RI Selama Pandemi Covid 19. https://www.cnbcindonesia.com/market/2020091011180117185785/sudah-7-kali-trading-halt-bursa-ri-selama-pandemi-covid-19, diakses 15 Pebruari 2021. http://ejournal.feunhasy.ac.id/dinamis 